\title{
Review
}

\section{Cell cycle regulation by the B-Myb transcription factor}

\author{
M. Joaquin * ${ }^{*}$ and R. J. Watson \\ Ludwig Institute for Cancer Research and Department of Virology, Faculty of Medicine, St Mary's Campus, \\ Imperial College London, Norfolk Place, London W2 1PG (United Kingdom)
}

Received 29 January 2003; received after revision 2 May 2003; accepted 13 May 2003

\begin{abstract}
The expression of genes required for progression through the cell cycle is highly modulated through a regulatory axis containing the E2F transcription factor and retinoblastoma tumour suppressor protein families. One of the genes regulated through this mechanism encodes the B-Myb transcription factor, which has been shown to be critically required for early embryonal development in the mouse. Transcriptional activity of B-
\end{abstract}

Myb is substantially enhanced in S phase through modification by cyclin $\mathrm{A} / \mathrm{cdk} 2$, and the evidence points squarely to the major role being played by B-Myb during this phase of the cell cycle. We discuss in this review recent findings suggesting that B-Myb is a multifunctional protein that has, in addition to its transcriptional properties, the ability to interact directly with other regulators of the cell cycle.

Key words. B-Myb; E2F; p107; cyclin/cdk; phosphorylation; cell cycle; gene repression; transcriptional regulation.

\section{Introduction}

The vertebrate Myb transcription factors comprise a small family of important regulatory proteins. The prototypical member, c-Myb, is the cellular progenitor of the oncogene carried by the AMV and E26 chicken retroviruses that transform haematopoietic cells in vivo and in vitro (reviewed in [1]). Two other members of this family, A-Myb and B-Myb, were subsequently discovered using a c-Myb probe to screen human cDNA libraries [2]. These three Myb proteins share a similar domain organisation (see fig. 1 for B-Myb domains). The most conserved region is the DNA-binding domain located in the $\mathrm{N}$ terminus, which is composed of three imperfect repeats of 51-52 amino acids that recognise the canonical Mybbinding site (MBS) C/TAACNG $[3,4]$. The central portions of these proteins comprise a less highly conserved acidic domain which is involved in transcription activa-

\footnotetext{
* Corresponding author.

$\uparrow$ Current address: Friedrich Miescher Institute, Maulbeerstrasse 66, 4058 Basel (Switzerland), e-mail: mjoaquin@fmi.ch
}

tion and a conserved region (CR) which has variously been associated with positive and negative effects on transcriptional activity [5-9]. The $\mathrm{C}$ terminus comprises an autoregulatory domain (negative regulatory domain: NRD) that suppresses transactivation function $[6,8$, 10-14].

The fact that three different Myb proteins have been found in higher vertebrates suggests that they have specific and distinct functions. c-Myb is expressed at high levels in most haematopoietic precursor cells and plays a crucial role in blood cell development $[1,15,16]$. Indeed, mice lacking a functional $c-m y b$ gene die at day 15 of gestation with multiple defects in fetal liver haematopoiesis [17]. $A-m y b$ is widely expressed in mitotically active cells during embryogenesis and in the developing central nervous system, sperm cell precursors, female breast ductal epithelium and B lymphocytes [18]. Consistent with this expression pattern, male mice lacking A-Myb are infertile because of a block in spermatogenesis, and $A-m y b$ null females have underdeveloped breast tissue after pregnancy [19]. In marked contrast to the restricted expression patterns of $c-m y b$ and $A-m y b, B-m y b$ is widely 


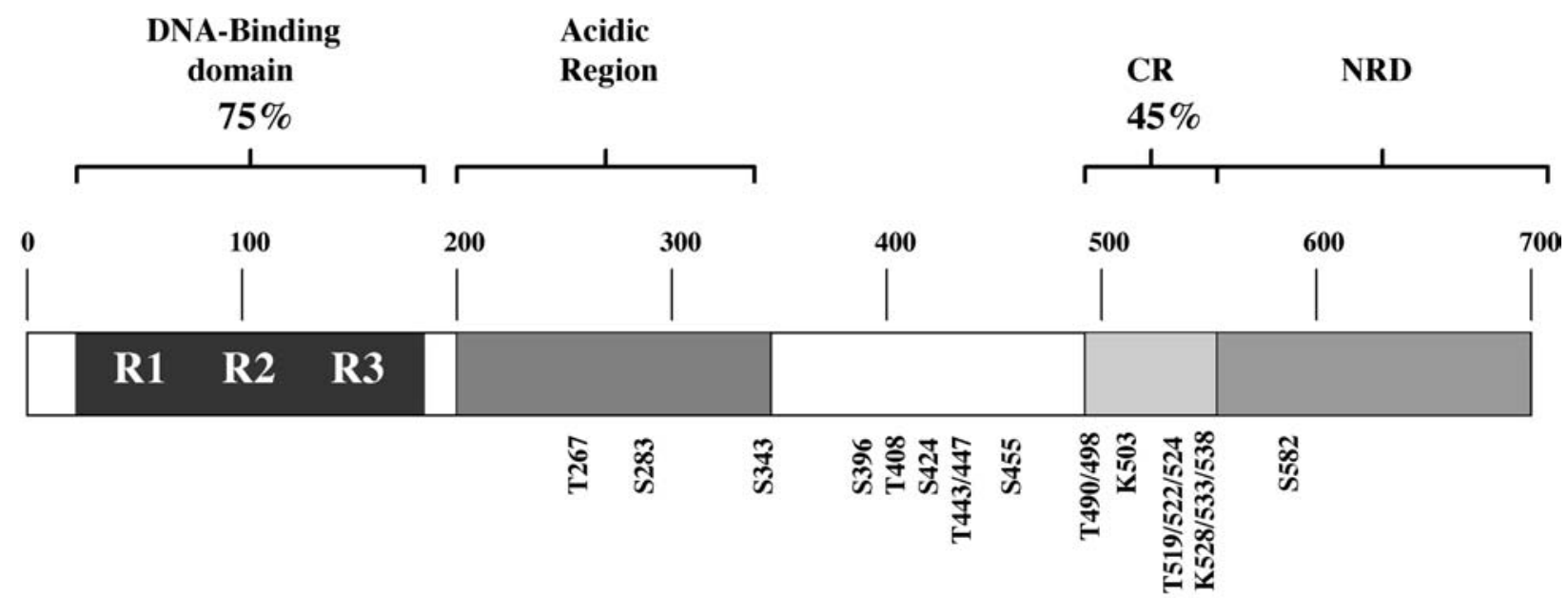

Figure 1. The B-Myb protein. Schematic representation of the B-Myb protein showing the described domains: the N-terminal DNA-binding domain is composed of three subdomains R1, R2 and R3. The overall amino acid identity of this region among Myb proteins is $75 \%$. Also shown are the adjacent acidic region, the conserved region (CR, which has an amino acid identity of $45 \%$ among Myb proteins) and the negative regulatory domain (NRD). The serine and threonine residues phosphorylated by the action of cyclin/cdk2 kinases are shown (amino acid residues shown relate to mouse B-Myb). The four conserved lysine residues which are putatively acetylated by $\mathrm{CBP} / \mathrm{p} 300$ are also indicated.

expressed in cycling cells of all lineages [2, 16, 20-22]. $B-m y b$ is expressed early during mouse embryogenesis, before either $c-m y b$ or $A-m y b$, and its expression is restricted to zones of cell proliferation [23]. Consistent with this, $B-m y b$ knock-out mice die at a very early stage of development (E4.5-E6.5), and a requirement for BMyb in inner cell mass formation is indicated by the severely impaired proliferation of these pluripotent cells when blastocysts were explanted and cultured in vitro [24].

The fact that $B-m y b$ expression is strongly associated with proliferating cells of all lineages suggests that this gene may play an important and general role during the cell cycle. This notion is supported by studies showing that $B-m y b$ antisense oligonucleotides inhibit proliferation of myeloid, lymphoid, glioblastoma, fibroblast and neuroblastoma cell lines [25-28], while constitutive $B$ $m y b$ expression allows BALB/c $3 \mathrm{~T} 3$ fibroblasts to grow in low serum conditions [26] and prevents cell cycle arrest in interleukin (IL)-6-induced differentiation of M1 myeloid leukaemia cells [29]. The purpose of this review is to discuss recent developments in our knowledge of $B$ $m y b$ regulation during the cell cycle and to suggest what part B-Myb may have in regulating cell proliferation.

\section{Cell cyle regulation of $B-m y b$ transcription}

The fact that $B-m y b$ transcription is very tightly regulated during the cell cycle provides a key piece of evidence that the B-Myb protein provides a function required in proliferating cells. Thus, early studies showed that $B-m y b$ mRNA levels were undetectable by Northern blot in murine fibroblasts and human keratinocytes arrested by serum deprivation $[20,21,30]$, and in quiescent human $T$ and B lymphoid cells [16]. After stimulation of these cells, $B-m y b$ expression was not induced until mid to late $\mathrm{G} 1$, and reached its maximum levels during $\mathrm{S}$ phase. Moreover, in G2/M synchronised NIH 3T3 fibroblasts, $B-m y b$ mRNA levels were found to decrease in G1 before again peaking at $\mathrm{S}$ phase, indicating that $B-m y b$ transcription is determined by the cell cycle phase rather than by the presence of mitogens [21].

Run-on transcription studies showed that $B-m y b$ mRNA induction in late G1 is due largely to an increase in gene transcription [21], suggesting that $B-m y b$ may be an E2F transcription factor-regulated gene. Indeed, the promoters of both the mouse and human $B-m y b$ genes contain a perfectly conserved E2F-binding site (fig. 2) which we showed is critical for cell cycle regulation of transcription $[30,31]$. Mutation of the $B-m y b$ promoter E2F-binding site resulted in constitutively high levels of expression throughout the cell cycle, a finding which ran counter to the prevailing view of the time that E2F is an activator of transcription. Co-expression of the $12 \mathrm{~S}$ adenovirus E1A or human papillomavirus type $16 \mathrm{E} 7$ genes enhanced the activity of the wild-type $B-m y b$ reporter activity, but not that of a $B-m y b$ promoter carrying a mutated E2F site. Since E1A and E7 target the Rb family of pocket proteins and disrupt their binding to $\mathrm{E} 2 \mathrm{~F}$, the $B-m y b$ promotor was postulated to be regulated by transcriptional repression involving E2F complexes bound to members of the $\mathrm{Rb}$ family [31, 32]. Activation of transcription in late G1 would then utilise constitutively bound transactivators, such as Sp1, which recognise sites upstream of the E2F site, and whose activity is presumably suppressed in 


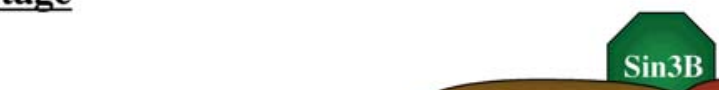

$\operatorname{Sin} 3 B$

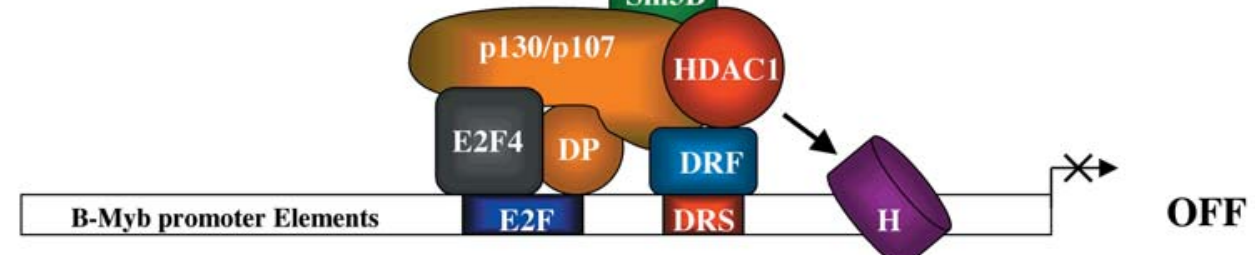

late G1
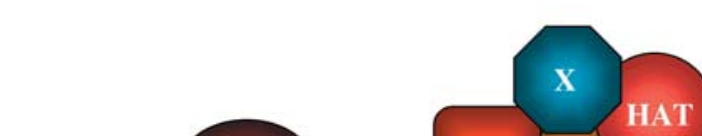

$\mathrm{Sp} 1$

B-Myb promoter Elements
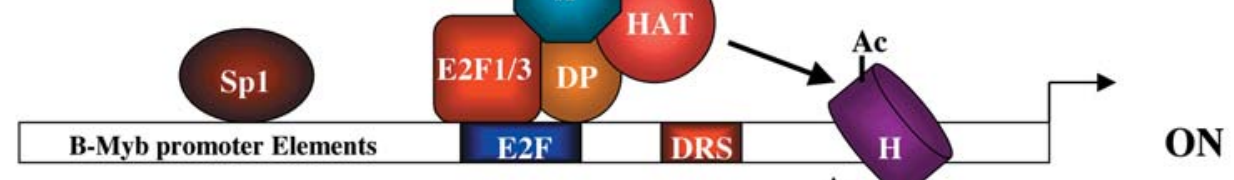



$\mathbf{S}$

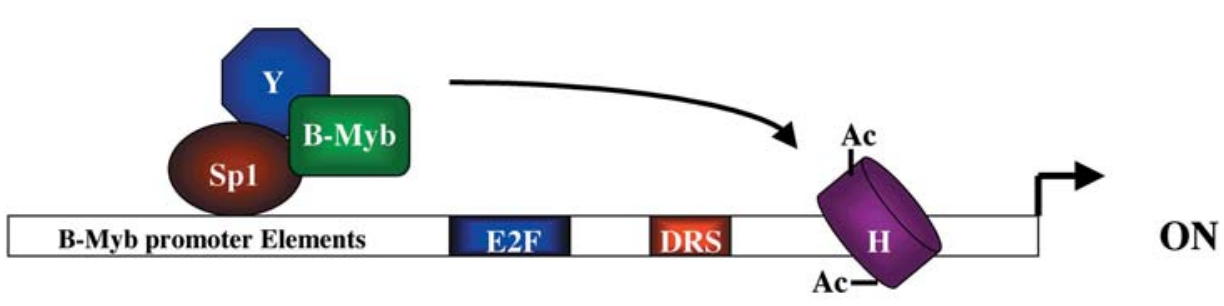

Figure 2. $B-M y b$ : a cell cycle-regulated gene. The $B-m y b$ gene is precisely regulated along the cell cycle. In quiescent and G0-arrested cells, the $B-m y b$ promoter is highly repressed by a protein complex bound to the E2F site and downstream repression site (DRS). Among the proteins identified to date which are involved in $B-m y b$ repression are E2F4 and its partner DP, the Rb proteins p107 and p130, the histone deacetylase $\mathrm{HDAC} 1$ and the repressor $\mathrm{mSinB} 3$. Although the relevance of the DRS site on $B-m y b$ gene regulation has been well established, the nature of the downstream regulatory factor (DRF) has yet to be characterized. In this phase of the cell cycle, histones are mainly deacetylated. During mid to late G1, the repressor complex is removed and substituted by other proteins, and E2F1/3-DP complexes are transiently detected at that stage. The presence of histone acetylases (HATs) has also been described and may be responsible for the histone acetylation detected in this phase. Since HATs do not directly bind to DNA, they may interact through E2F1/3 (as described for $\mathrm{CBP}$ ) or through additional factors (X) yet to be characterised. At the $\mathrm{S}$ phase of the cell cycle, $B$-my $b$ transcription is fully derepressed and the promoter reaches its highest activity. During that phase, the E2F and DRS sites are unoccupied and histone acetylation is at its maximum. Transcription may also be driven by the cooperative activity of SP1 and B-Myb itself. The involvement of unknown proteins bridging $\mathrm{Sp} 1$ and B-Myb is also possible.

G0/early G1 by E2F/pocket protein complexes. In this simple model, activation of transcription therefore reflects derepression of the promoter (fig. 2).

The precise mechanism operating on transcriptional regulation of $B-m y b$ has been the subject of several studies. Using E7 mutants that discriminate between pocket proteins, we deduced that transcriptional repression depended on $\mathrm{p} 107 / \mathrm{E} 2 \mathrm{~F}$ rather than $\mathrm{Rb} / \mathrm{E} 2 \mathrm{~F}$ complexes in NIH3T3 fibroblasts [32]. In other cell types, p130 was the predominant protein found in E2F complexes binding to the $B-m y b$ promoter during quiescence $[30,33]$. Evidence supporting the notion that $B-m y b$ promoter repression requires either p107 or p130 has come from studies of embryonic fibroblasts derived from gene knock-out mice [34]. Significantly, $B-m y b$ expression was unaffected in mouse embryo fibroblasts (MEFs) derived from either $p 107^{-/}$or $p 130^{-/}$knock-out animals; however, in double-knock-out $p 107^{--} ; p 130^{--}$MEFs, B-myb transcription was strongly derepressed during G0/early G1.
Other genes such as $c d c 2, E 2 F 1$ and $c y c l i n A 2$ were also deregulated in these cells. In contrast, $B-m y b$ expression was unaffected in $R b^{-/}$MEFs, although the cyclin $E$ and p107 genes were strongly deregulated in these cells. This study indicates a functional redundancy between p107 and p130 in repression of $B-m y b$ transcription during G0/early G1 that cannot be compensated for by Rb. Con-

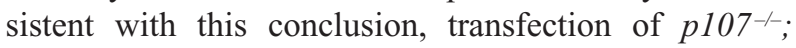
$p 130^{-/}$MEFs with either $\mathrm{p} 107$ or $\mathrm{p} 130$ repressed the $B-m y b$ promoter, whereas $\mathrm{pRb}$ had no significant effect $[34,35]$.

The major question that arises from these findings is how does the $B-m y b$ promoter discriminate between E2F complexes containing p107/p130 and Rb? Certainly, Rb/E2F complexes are able to bind to the $B-m y b$ promoter in in vitro electrophoretic mobility shift assays (EMSAs) and, notably, these complexes are very abundant in quiescent p107 $7^{-<} ; p 130^{-/}$MEFs [34, 35]. However, in vivo methylation footprinting showed that the $B-m y b$ E2F site was 
unprotected in $p 107^{--} ; p_{130^{-/}}$MEFs, indicating the absence of interacting E2F complexes in these cells, whereas the site was protected in wild-type and $R b^{-/}$ MEFs. Similar footprinting studies showed that this site is occupied in vivo in G0/early G1 when the $B-m y b$ promoter is repressed, but unoccupied at late $\mathrm{G} 1 / \mathrm{S}$ when $B$ $m y b$ is expressed [36]. Notably, the latter study suggests that activating E2F species (i.e. E2F-1, E2F-2 and E2F-3 unbound to pocket proteins), which are prevalent at late $\mathrm{G} 1 / \mathrm{S}$, do not bind stably to the $B-m y b$ promoter. This conclusion is consistent with the notion that $B-m y b$ transcription is regulated predominantly by a repressionderepression mechanism [31]. Overall, these findings suggest that discrimination between E2F complexes binding to the $B-m y b$ promoter depends upon chromatin structure rather than the primary DNA sequence. The most informative studies in this area are therefore those which look at what is going on in intact cells, and particularly useful in this respect is the chromatin immunoprecipitation (ChIP) assay.

ChIP assays carried out with NIH 3 T3 fibroblasts showed that E2F-4/p107 and E2F-4/p130 complexes were associated with the $B-m y b$ promoter in G0, while in early $\mathrm{G} 1$, only E2F-4/p107 complexes remained [37]. Free E2F-4 (i.e. devoid of pocket proteins) was detected transiently on the $B-m y b$ promoter at the $\mathrm{G} 1 / \mathrm{S}$ transition, although no other E2F species were seen at this stage, while in $\mathrm{S}$ phase, no E2F or pocket proteins could be detected at all. This latter situation is unique to $B-m y b$, since all other E2F-regulated promoters analysed bind E2F species during S phase [37]. Another study using the human T98G glioblastoma cell line also found that the $B-m y b$ promoter is uniquely free of associated E2F and pocket proteins during $\mathrm{S}$ phase [38], although some details of the factors binding in G1 differed between this cell line and NIH 3T3 cells. The major discrepancy is that E2F-1 and E2F-3, but not E2F-4, were found to be associated with the $B-m y b$ promoter in T98G cells in late G1.

Although the predominant E2F complexes binding to the $B-m y b$ promoter are associated with pocket proteins and are likely to repress transcription, free E2F species were detected transiently in late G1, implying that they may have a role in transactivating the promoter. This notion is consistent with studies carried out in $E 2 \mathrm{F3}^{-/-} \mathrm{MEFs}$, where the expression of $B-m y b$ and other cell cycle regulated genes such as $c d c 2$, cyclin $A 2$ and $c d c 6$ is strongly impaired when quiescent cells are stimulated to reenter the cell cycle by addition of serum. In contrast, none of these genes was found to be deregulated in $E 2 F 1^{--} \mathrm{MEFs}$ [39]. This study suggests that E2F-3 has a transient role in transactivating the $B-m y b$ promoter late in $\mathrm{G} 1$, at least in certain cell types. In opposition to this notion, a $B-m y b$ promoter containing a mutated E2F site was found to be highly active in stably transfected NIH 3 T3 cells [40]. Altogether, this may point to E2F-3 activation operating through an alternative binding site in $B-m y b$, potentially a site which is not present in the promoter sequences used in transfection experiments, and the resolution of this issue requires further study.

$B-m y b$ is a highly repressed gene in quiescent cells, and recent studies have begun to address how this is achieved. Core histones on the $B-m y b$ promoter are under-acetylated in G0/early G1 when transcription is silenced, while $B-m y b$ derepression correlates with an increase in $\mathrm{H} 3$ and $\mathrm{H} 4$ acetylation [38]. These findings suggest that $\mathrm{p} 107$ and p130 may recruit histones deactetylases (HDACs) to the $B$-myb promoter at G0/early G1 and that histone acetylases (HATs) may replace HDACs during the G1/S transition (fig. 2). Indeed, ChIP analysis carried out on fibroblasts detected the presence of HDAC1 and the co-repressor mSin3B on the $B-m y b$ promoter during G0 [40]. Notably, the recruitment of HDAC1 and mSin3B was not observed in $p 107^{-/} ; p 130^{-/-}$MEFs and was completely abolished in a $B-m y b$ transgene harbouring a mutated E2F site. Therefore, E2F4 complexes containing p107/ p130 may repress $B-m y b$ transcription by either recruiting HDACs and co-repressors or by physically excluding HATs from the promoter at G0/early G1 (fig. 2).

As noted above, regulation of $B-m y b$ transcription by $\mathrm{E} 2 \mathrm{~F}$ has some unconventional features, most notably the prevalence of repressor complexes and the complete absence of associated E2F species during S phase. This eccentricity suggests unique features of the $B-m y b \mathrm{E} 2 \mathrm{~F}$ site, or its context. Consistent with this notion, we encountered a co-repressor site (fig. 2) referred to as the downstream repression site (DRS), which is located just a few nucleotides 3' of the E2F site [33]. Mutation of the DRS resulted in $B-m y b$ promoter derepression in $\mathrm{G} 0$ in a similar manner to mutations in the adjacent E2F site. Curiously, mutating the DRS had no effect on E2F binding in in vitro assays such as EMSA [33]. Recently, however, ChIP assays carried out on a $B-m y b$ transgene harbouring mutations in the DRS have shown that p130 and p107 binding to the E2F site is compromised in vivo [35]. We conclude that the DRS acts specifically in vivo to recruit repressor E2F-4/p107 and E2F-4/p130 complexes to the adjacent E2F site, potentially by modifying the nucleosome conformation or positioning in this region (fig. 2). The presence of the DRS may therefore explain why repressor E2F complexes predominate on the $B-m y b$ promoter.

Virtually all studies on $B-m y b$ transcriptional regulation have been done with cells arrested in, and released from, G0, and there is relatively little information on what happens when cells receive an inhibitory stimulus and arrest at a cell cycle checkpoint. G1 arrest triggered by $\mathrm{p} 16^{\mathrm{INK} 4 \mathrm{a}}$, transforming growth factor- $\beta$ (TGF- $\beta$ ) and contact inhibition is mediated by E2F-dependent transcriptional repression [41], and TGF- $\beta$-induced G1 arrest has been suggested to result from its inhibitory effect on expres- 
sion of $B-m y b$ and cyclin A [42]. A recent report by Chen and collegues has elucidated the cascade of events that links the activation of the TGF- $\beta$ receptor with $c-m y c$ transcriptional repression [43]. Thus, TGF- $\beta$ receptor activation induces phosphorylation of the Smad3 protein, some of which exists as a cytosolic complex with E2F3/4DP1 and p107. Phosphorylated Smad3 is able to recruit Smad4 and translocate the multicomplex to the cell nucleus, where it represses TGF- $\beta$-responsive genes like $c$-myc. Clearly, it is of interest to determine whether a similar mechanism acts on $B-m y b$ transcription.

\section{Cell cycle-regulated phosphorylation of B-Myb}

Reflecting the strict transcriptional regulation of the $B$ $m y b$ gene during the cell cycle, B-Myb protein levels are low in G0-arrested cells, but are induced in late G1 following serum stimulation and peak at the onset of $\mathrm{S}$ phase [44]. Interestingly, induction of expression in late $\mathrm{G} 1 / \mathrm{S}$ is accompanied by the appearance of a more slowly migrating B-Myb form that runs at an apparent molecular weight of $112 \mathrm{kDa}$. Treatment of cell extracts with phosphatases reduced the apparent molecular weight of BMyb to $110 \mathrm{kDa}[12,44]$, similar to that seen in G0/early G1. These reports were the first to show that B-Myb was modified by phosphorylation during $\mathrm{S}$ phase. The timing of this modification correlated with cyclin $\mathrm{E}$ and cyclin A-cdk2 activation [45], and these cyclin/cdk complexes are the most likely candidates to phosphorylate B-Myb. Indeed, using baculovirus-expressed proteins, B-Myb was shown to be preferentially a substrate for cyclin $\mathrm{A} / \mathrm{cdk} 2$ activity [44], while cyclin $\mathrm{E} / \mathrm{cdk} 2$ and cyclin D1/cdk4 had little effect. Moreover, cyclin A was able to induce a B-Myb mobility shift in transfected COS-7 and U-2 OS cells $[12,46]$, while both cyclin A and cyclin E were able to do so in Saos 2 cells [47]. Importantly, cotransfection of cyclin A/cdk2 with B-Myb was found to result in a substantial enhancement of transactivation function $[8,11,12,47]$, suggesting that the transcriptional properties of B-Myb are positively regulated by cyclin/cdk-mediated phosphorylation at late G1/S phase.

Further evidence that cyclin A/cdk2 is primarily responsible for B-Myb phosphorylation in $\mathrm{S}$ phase has come from two-dimensional tryptic peptide mapping. This showed that cyclin A/cdk2 phosphorylated similar BMyb sites both in vitro and in vivo; furthermore, the spot pattern was very similar to that obtained from $\mathrm{S}$ phasesynchronised Swiss 3T3 fibroblasts [12]. The use of this methodology in combination with point mutagenesis of putative cdk phosphorylation sites (Ser/Thr-Pro) allowed the indentification of Thr443/447/490/497/524 and Ser581 as in vitro and in vivo cyclin A/cdk2 substrates [46, 48, 49]. Notably, B-Myb transcriptional activity was reduced between $40-50 \%$ with respect to wild type B-
Myb in the single point mutants T447A, T524A and S581A, while a mutant harbouring four mutated sites (T447A, T490A, T497A and S581A) was barely activated by ectopic cyclin A $[46,48]$. Thus, the co-ordinated phosphorylations of different $\mathrm{Thr}$ and Ser residues in the B-Myb C terminus synergise to increase B-Myb transcriptional activity. More recently, the use of automated phosphopeptide radiosequencing has allowed the identificaction of several more cyclin E/A-cdk2 phosphorylation sites in B-Myb (fig. 1), and a mutant carrying substitutions in all 15 reported B-Myb phosphorylation sites is unable to transactivate the FGF4 promoter and behaves as a dominant negative, presumably by competing with wild-type B-Myb for binding to MBSs $[50,51]$.

The B-Myb C-terminus (fig. 1) contains an NRD, and its deletion generates proteins with high transcriptional activity that cannot be further activated by phosphorylation $[8,11,12,52]$. The role of phosphorylation has therefore been postulated to overcome negative regulation conferred by the NRD, and a number of studies have investigated how this mechanism may operate at the protein interaction level. One possible mechanism was suggested by the observation that one of the phosphorylation sites (S581) lies within a nuclear localisation domain. However, mutation of this site had no effect on intracellular localisation of B-Myb; moreover, the B-Myb protein remains in the cell nucleus throughout the cell cycle suggesting that phosphorylation has no effect on this property [44]. A further mechanism was suggested by the observation that C-terminally truncated B-Myb has an increased affinity for DNA [52]. However, binding of fulllength B-Myb to either a single or a concatenated MBS was not increased upon cyclin A-mediated phosporylation. Currently, the most favoured models for B-Myb activation by phosphorylation are either that this increases the affinity of B-Myb for a co-activating protein or, alternatively, reduces its affinity for a repressor protein.

\section{B-Myb co-activators}

In common with other Myb proteins, B-Myb has been found to interact both functionally and physically with the transcriptional co-activators, CREB-binding protein (CBP) and the related p300 protein [51-53]. Both these co-activators respond to multiple signalling events by acting as scaffolding proteins that connect sequence-specific transcription factors to the basal transcriptional machinery. Additionally, p300 and CBP have intrinsic HAT activity, and therefore may be involved in chromatin remodelling through acetylation of nucleosomal histones as well as by modifying interacting transcription factors such as B-Myb [reviewed in ref. 54]. The ability of CBP to synergise with B-Myb transcriptional activity was 
found to be strictly dependent on cyclin A-mediated phosphorylation of B-Myb [52]. Surprisingly, in view of this finding, evidence obtained to date indicates that the phosphorylation status of B-Myb does not affect binding to either CBP or p300 [51, 52]. Explaining these somewhat discordant findings is uncertain at present, but a simple model in which $\mathrm{CBP} / \mathrm{p} 300$ activates the transactivation function of B-Myb by specifically recognising phosphorylated domains is clearly a non-starter. Pertinent is that $\mathrm{CBP} / \mathrm{p} 300$ acetylates five lysine residues in the NRD of the mouse c-Myb protein and their substitution to arginine strongly impairs c-Myb transcriptional activity $[55,56]$. Since four of these lysine residues are conserved in B-Myb, one may reasonably argue that lysine acetylation is an important post-translational modification with huge implications for Myb function. One possible explanation of the results, therefore, is that cyclin Amediated phosphorylation of key serine and threonine residues located in the $\mathrm{CR} / \mathrm{NRD}$ domain of B-Myb may alter the conformation of this region and allow the associated CBP/p300 access to the substrate lysines. The subsequent acetylation of these residues would account for the synergy between cyclin A and CBP/p300, and would explain why inhibiting phosphorylation ablates enhance- ment of B-Myb transcriptional activity. Further work in this area is required to resolve these issues.

The poly(ADP-ribose) polymerase (PARP) protein has also been reported to be a co-activator of B-Myb [57]. This activity is dependent upon a physical interaction between these proteins which involves the B-Myb DNAbinding domain, but is not dependent upon the poly-ADP ribosylation activity of PARP. Notably, PARP and cyclin A synergise to drive B-Myb transcriptional activity [58], while a B-Myb mutant containing substitutions in ten cyclin A/cdk2 phosphorylation sites [50] failed to be co-activated by PARP expression. Although these data initially suggested that PARP interacts specifically with phosphorylated B-Myb, further evidence indicated that in fact PARP facilitates phosphorylation of B-Myb. Indeed, cyclin A was found to be unable to enhance B-Myb activity in PARP ${ }^{-/}$fibroblasts, suggesting that PARP might induce a conformational change in B-Myb that would expose C-terminal phosphorylation sites to cyclin $\mathrm{A} / \mathrm{cdk} 2$ [58]. These data suggest that synergy between B-Myb and $\mathrm{CBP} / \mathrm{p} 300$ could also be accounted for by a similar mechanism, as indeed we have previously proposed [52]. The interactions made by B-Myb with co-activators are summarized in figure 3 .

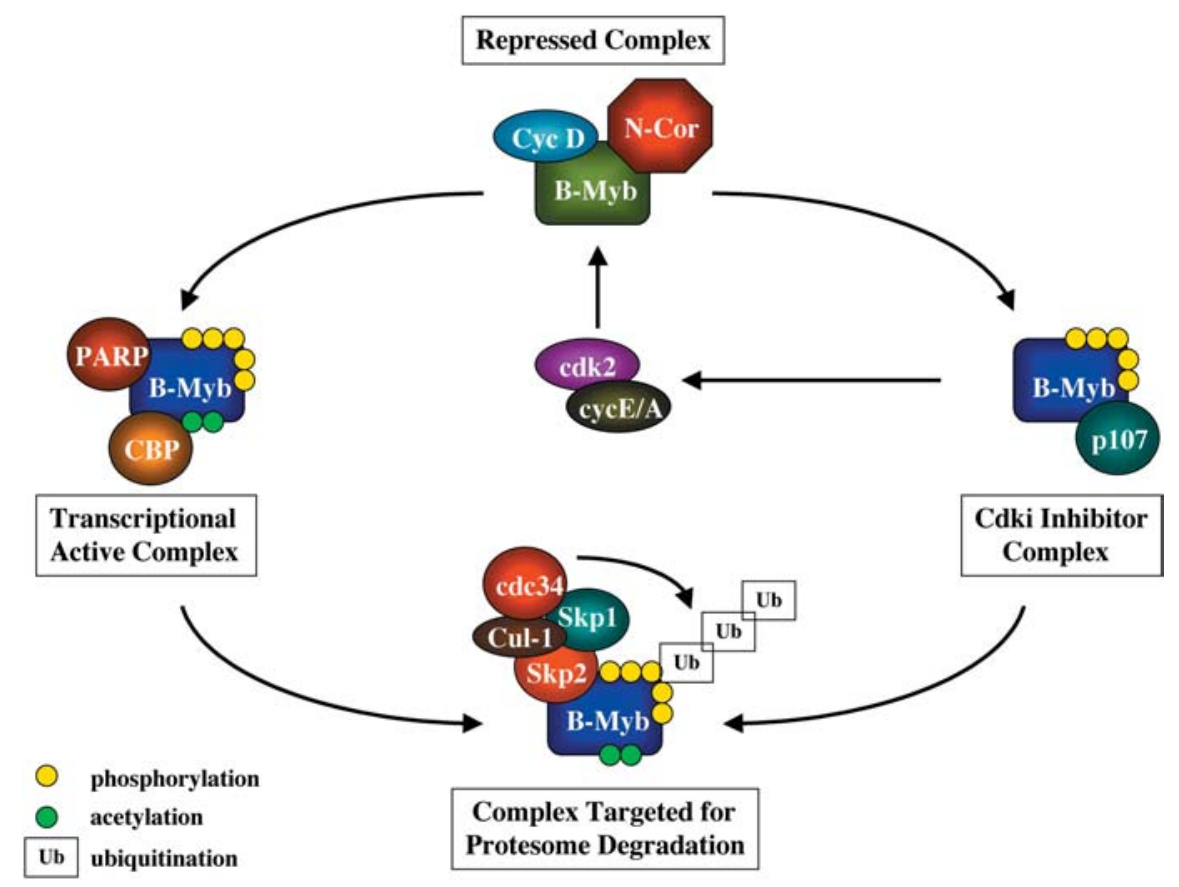

Figure 3. The B-Myb cycle: from birth to death. The B-Myb protein is highly repressed through its interaction with proteins such as cyclin D1 and N-CoR. As cells progress to G1, cyclin D1 is degraded and removed from the complex. Additionally, B-Myb undergoes protein phosphorylation by the activities of the cyclin/cdk2 kinase complexes. As a consequence, B-Myb is released from the N-CoR complex and becomes transcriptionally active. That activity may be further increased by the association of B-Myb with the co-activators PARP and $\mathrm{CBP} / \mathrm{p} 300$. The latter is also responsible for B-Myb acetylation, which may result in a further increase in gene transcriptional activity. On the other hand, B-Myb protein binds to the cyclin-binding domains of the RB protein $\mathrm{p} 107$. As a result, cyclin/cdk2 kinase complexes are further activated generating more phosphorylated B-Myb. Phosphorylated B-Myb is recognised by p45Skp2, the F component of the SCF complex formed by Skp1 and Cul-1, which has E3 ubiquitin ligase activity. Ubiquitinated B-Myb is rapidly targeted for degradation by the 26S proteasome. 


\section{B-Myb repressors}

The transcriptional activity of B-Myb is repressed through interactions with the co-repressor proteins $\mathrm{N}$ CoR/SMRT [53, 59] and BS69 [59]. The closely related $\mathrm{N}-\mathrm{CoR}$ and SMRT proteins are components of multiprotein complexes containing HDACs, which bind and repress many other transcription factors [60]. The B-Myb C terminus has recently been shown to interact with the nuclear receptor-binding domain of N-CoR, and transcriptional repression of B-Myb can be overcome by co-expressing the unliganded thyroid hormone nuclear receptor. Repression of B-Myb activity can also be overcome with the HDAC inhibitor trichostatin A (TSA), which suggests that recruitment of HDACs to an N-CoR/B-Myb or SMRT/B-Myb complex may account for the inhibitory effect. Significantly, the association with N-CoR was reduced when B-Myb was modified by cyclin A/cdk2 [53]. Furthermore, $\mathrm{N}-\mathrm{CoR}$ is unable to bind to transcriptionally activated mutants of B-Myb which lack the NRD. These findings suggest a model in which N-CoR/SMRT binding to $\mathrm{B}-\mathrm{Myb}$ is disrupted by cyclin $\mathrm{A} / \mathrm{cdk} 2$ phosphorylation (fig. 3). This would enable the acetylase activity provided by $\mathrm{B}-\mathrm{Myb}$-associated $\mathrm{CBP} / \mathrm{p} 300$, now unfettered by HDAC activity associated with N-CoR/SMRT, to modify histones and other regulatory proteins (possibly including B-Myb itself) and stimulate transcription. Cterminally truncated B-Myb lacking the NRD would not require phosphorylation for this activity, as it does not bind N-CoR/SMRT. Although this is an interesting model, further work is required to prove its validity. Indeed, other researchers find that C-terminally truncated B-Myb binds N-CoR as efficiently as wild-type B-Myb [59], and suggest that physical interactions with the BS69 protein, which was first identified as a protein that binds and inhibits the adenovirus 5 E1A oncogene [61], contributes to the transcriptional repression activity of B-Myb.

\section{Role of ubiquitination in regulating B-Myb activity}

Another means to control protein activity is at the level of protein stability, and many regulators of the cell cycle and transcription are in fact short-lived proteins regulated by protein degradation through the ubiquitin-proteasome pathway $[62,63]$. B-Myb protein levels were initially observed to be substantially reduced when cyclin A was coexpressed [46], suggesting that phosphorylated B-Myb may be targeted for ubiquitination. Indeed, the B-Myb protein half-life was found to be reduced from $2.7 \mathrm{~h}$ to 50 min after cyclin A expression, while this effect was compromised by proteasome inhibitors such as lactacystin [64]. Moreover, poly-ubiquitination of wild-type B-Myb was increased in cyclin A-co-transfected cells while it barely affected the half-life of a C-terminally truncated protein, namely B-Myb ${ }_{1-508}$. Degradation of B-Myb was accelerated in cells co-transfected with the F-box protein $\mathrm{p} 45^{\text {Skp2 }}$, which is a cell cycle-regulated component of the ubiquitin/proteasome pathway maximally expressed during S phase [64]. Ubiquitination of cyclin $\mathrm{A} / \mathrm{cdk} 2$-modified B-Myb may therefore have a role in limiting the transcriptionally hyperactivated protein to $\mathrm{S}$ phase. More speculatively, proteasomal targeting of phosphorylated B-Myb may generate transcriptionally activated fragments from which the NRD has been excised. However, there is no evidence that C-terminally truncated B-Myb fragments accumulate in cells expressing cyclin $\mathrm{A} / \mathrm{cdk} 2$ as would be predicted by this model [46].

\section{B-Myb cell cycle regulation: transcription factor activity}

The most obvious requirement for B-Myb function in the cell cycle is as a regulator of gene transcription Indeed, the experimental use of inducible dominant interfering Myb proteins, consisting of the DNA-binding domain linked to a regulatable estrogen receptor/engrailed transcriptional repression module $[52,65]$, suggests that the transcriptional activity of $\mathrm{B}-\mathrm{Myb}$ is required for cell growth. These interfering proteins were designed to bind to MBSs present in the transcriptional regulatory sequences of target genes, blocking transcription through the action of the Engrailed repression domain. Mouse embryonal stem (ES) cells expressing an interfering Myb protein showed a defect in G1/S transition and an apparently independent reduction in cell adhesion. Although all three members of the vertebrate Myb family bind the same consensus MBS, and therefore may regulate the same gene set, the defects observed are likely due to interference with B-Myb-regulated transcription, since this is the only member of the family which is expressed in these primitive progenitor cells. Which target genes are affected by the interfering Myb mutant remains unknown.

B-Myb notably binds the MBS less avidly than either cMyb or A-Myb and has less tolerance of binding site variations [66]. This suggests that B-Myb is a weaker transcriptional activator which could be supplanted by the other Myb family proteins in cells where they are co-expressed. However, studies to date indicate that B-Myb gene transactivation is not straightforward, being in some instances independent of DNA binding and, as discussed above, clearly affected by post-translational modifications and by the presence of co-repressors and co-activators. As discussed in detail below, a number of potential $\mathrm{B}-\mathrm{Myb}$ target genes have now been proposed, and B-Myb has evidently evolved several strategies to regulate transcription. 
MBS-independent promoter regulation is best exemplified by the human HSP70 gene. Expression of HSP70 peaks during $\mathrm{S}$ phase [67], and it is notable that this coincides with maximal levels of B-Myb $[21,30]$. Transactivation of the HSP70 promoter is abrogated by removal of the TATA box, suggesting that in this case B-Myb may regulate gene transcription through direct or indirect interactions with components of the basal transcriptional machinery [68]. Recently, B-Myb was suggested to be titrating out the transcriptional co-repressor $\mathrm{N}-\mathrm{CoR}$ and releasing the nuclear hormone receptor $\mathrm{TR} \beta$, which would then directly transactivate the HSP70 promoter [53].

A number of other promoters which lack MBSs have also been reported to be transactivated by B-Myb, for example, DNA polymerase alpha [69], B-myb itself [70] and the fibroblast growth factor 4 (FGF4) promoter [51]. Although some caution is advisable in the interpretation of these results - in particular, evidence is lacking that these genes are bona fide in vivo targets for B-Myb - the ability of B-Myb to act as a promiscuous, albeit rather weak, transactivator must reflect some significant property of the protein. In this respect, of interest is that B-Myb acts through a GC-rich region containing several putative Sp1-binding sites for transactivation of its own promoter [70]. Indeed, Sp1 was found to synergize with B-Myb to transactivate the $B-m y b$ promoter [70]; moreover, these proteins are able to interact in vivo. Association with $\mathrm{Sp} 1$ may therefore allow B-Myb to be recruited to promoters containing Sp1-binding sites (fig. 2). As these binding sites are common promoter components, this mechanism would potentially allow B-Myb recruitment to numerous genes.

B-Myb has been reported to transactivate a number of promoters through MBS-dependent regulation, although in general the data relate only to transient co-transfection/reporter assays. Transactivation of the c-myc protooncogene promoter by B-Myb appears to be mediated through several MBSs which are present in this sequence [71], while transactivation of the human DNA topoisomerase II $\alpha$ promoter appears to require a single MBS [72]. Although both of these genes have important roles in cell proliferation, there is as yet little evidence that the promoters of the endogenous genes are true targets for BMyb in vivo. Similarly, the human cyclin A1 promoter contains several MBSs close to the mRNA initiation site, and can be transactivated by B-Myb (and c-Myb) in transient co-transfection assays $[49,73]$. Cyclin A1 is expressed in proliferating cells during spermatogenesis and is also transcribed in myeloid leukaemias; B-Myb is coexpressed in these cells, and may potentially regulate its expression; however, further evidence is still required to confirm this. Both c-Myb and B-Myb have recently been shown to be able to bind to the insulin-like growth factorbinding protein 5 (IGFBP) promoter in vitro (EMSA as- says) and in vivo (ChIP assays), and can transactivate the promoter through an MBS. Notably, neuroblastoma cell growth is dependent on the supply of growth factors, which are frequently produced through an autocrine mechanism, suggesting that Myb proteins may be involved in the regulation of the insulin-like growth factor axis, and therefore may contribute to the neoplastic transformation of neuroblastoma cells [74].

Several studies suggest that B-Myb regulates genes which promote cell survival. Representational difference analysis carried out on LAN-5 neuroblastoma cells ectopically expressing B-Myb identified the apolipoprotein $\mathrm{J} /$ clusterin (clusterin) gene as a putative B-Myb target. The clusterin promoter has an MBS whose mutation impairs B-Myb transactivation in transient co-transfection assays; moreover, the activity of $\mathrm{B}-\mathrm{Myb}$ on this promoter is enhanced by cyclin A2 [75]. The clusterin gene encodes a sulphated glycoprotein which accumulates during senescence and in cancer cells, and has been found to protect cells against tumour necrosis factor $\alpha$ - and oxidative stress-related apoptosis [reviewed in ref. 76]. Additionally, clusterin expression appears to increase resistance of neuroblastomas to chemotherapeutic drugs, and of interest is that high levels of B-Myb expression in neuroblastoma correlates with poor prognosis [77]. B-Myb overexpression may therefore contribute to tumour progression in neuroblastomas by enhancing cell survival through induction of clusterin. Ectopic expression of BMyb has also been found to reduce the dependence of murine $T$ cells on cytokines while increasing their resistance to several apoptotic agents. This effect correlated with increased expression of the anti-apoptotic $B c l 2$ gene, and B-Myb and cyclin A were shown to co-operate to transactivate $B c l 2$ through a putative MBS found in the promoter [78]. Finally, B-Myb can transactivate the promoter of the surfactant protein A (SP-A) gene [79], whose protein functions as part of the innate immunity of the lung. Although the mitotic index of lung epithelia is normally low, cdk2 and cyclin A increase after lung injury and may activate B-Myb to induce expression of SP-A in these cells.

Interestingly, Myb proteins may also act as repressors of gene transcription, although again, this property of BMyb has been described only during over-expression in transfected cells. Thus, c-Myb and B-Myb repress transcription of the human c-erbB2 (HER2) promoter in an MBS-dependent way, potentially by binding to an MBS which overlaps with the TATA box and blocking access to TFIID [80]. HER2 is frequently amplified in breast adenocarcinomas [81], and it would be interesting to know if Myb proteins can down-regulate HER2 promoter activity in cancer cells. Moreover, the bFGF-induced decrease in mRNA levels and transcription of the type I collagen $\alpha 1$ and $\alpha 2$ genes in bovine aortic smooth muscle cells (SMCs) is paralleled with induction of $B-m y b$ mRNA lev- 
els [82, 83], and co-transfection experiments showed that B-Myb strongly repressed transcription from the promoters of these collagen genes. The repression mechanism is not yet known, but both promoters contain putative MBSs and B-Myb may prevent c-Myb from activating transcription through this site, as has been proposed for the human type I collagen $\alpha 2$ promoter [84]. However, BMyb appears to bind MBSs more weakly than does cMyb and, arguably, B-Myb would be a better competitor at the protein-protein interaction level rather than as a DNA-binding competitor. Indeed, transcriptional downregulation by B-Myb of the type $\mathrm{V}$ collagen $\alpha 2$ gene in aortic SMCs occurs through a promoter region which lacks MBSs, and this has been suggested to occur via interaction with a positively acting matrix regulatory factor, termed MRF-V [85]. Taken together, these findings show the relevance of Myb proteins as key regulators of collagen gene expression.

\section{B-Myb cell cycle regulation: interactions with regulatory proteins}

B-Myb has been reported to bind to several cell cycle regulatory proteins, including cyclin D1 [86], cyclin A1 [49] and p107 [87], suggesting that these interactions may contribute to the role of B-Myb in cell growth. In this respect, of great interest is that a dual role as transcriptional activator and component of a DNA replication complex has been proposed for the Drosophila Myb protein [88], which appears to be more closely related to B-Myb than to either c-Myb or A-Myb [89]. Moreover, some studies indicate that the ability of B-Myb to overcome inhibitory effects on the cell cycle does not depend upon its transcriptional activity. Thus, ectopically expressed B-Myb was found to bypass a proliferation block induced by p53/p21Cip1 in a human glioblastoma cell line [27], and this activity could also be conferred by a transcriptionally defective B-Myb mutant. We have been unable to demonstrate binding in vivo between B-Myb and either $\mathrm{p} 53$ or p21Cip1 [unpublished results], and the molecular mechanism behind this observation remains to be elucidated. Moreover, we have demonstrated that the ability of BMyb to overcome a G1 cell cycle block imposed by p107, a member of the retinoblastoma pocket protein family [90], is also independent of the transcriptional activity of B-Myb [91]. In Saos-2 cells, p107 causes G1 arrest through two mechanisms specified by distinct protein domains: the action of the large pocket domain that binds E2F and an extensive $\mathrm{N}$-terminal domain that binds and inhibits cyclin/cdk2 complexes $[92,93]$. We found that BMyb binds to the p107 $\mathrm{N}$ terminus (between amino acids 10-486) in a domain that overlaps a cyclin A/E-binding motif [91], suggesting that the critical function that BMyb bypasses is inhibition of cyclin/cdk2 activity. In sup- port of this notion, we could demonstrate that p107-mediated inhibition of cyclin E/cdk2 is overcome by B-Myb expression in co-transfected Saos-2 cells. Significantly, the $B-m y b$ and $p 107$ genes are both under E2F transcriptional control, and their expression is co-ordinately induced in late G1. One function of B-Myb therefore may be to counteract inhibition of cyclin/cdk2 activity by de novo synthesised p107 at the critical G1/S boundary (fig. $3)$. The requirement for this interaction may be cell type dependent and, of course, would be influenced by the relative abundance of B-Myb and p107. B-Myb is highly expressed in ES cells, whose growth appears to depend critically upon B-Myb [24], and the majority of p107 in these cells can be depleted by immunoprecipitating with a B-Myb antibody [unpublished results].

The domains of B-Myb required for p107 binding are quite ill-defined - deletions within the extreme C-terminal NRD as well as the acidic region both ablate binding [91] - suggesting that the interaction interface is conformational rather than linear. The involvement of the NRD raises the possibility that 107 binding may repress BMyb transcriptional activity through this domain. Clearly, however, B-Myb also makes interactions with other proteins through C-terminal sequences, including $\mathrm{N}-\mathrm{CoR}$, and function of the NRD is unlikely to be ascribable to association with a unique co-repressor protein.

Interactions with cyclin D1 and cdk9 do not appear to result in phosphorylation of B-Myb, and in neither instance does binding depend upon enzymatic activity associated with these proteins $[86,94]$. Rather, direct interactions with either cyclin D1 or cdk9 inhibit B-Myb transcriptional activity, indicating that these proteins are negative regulators (fig. 3). The association between endogenous B-Myb and cyclin D1 takes place in cells enriched at the G1/S boundary [86]. Since B-Myb function seems to be crucial during the G1/S transition, cyclin D1 may hold BMyb in a transcriptionally inactive complex in G1 until such time in late $\mathrm{G} 1 / \mathrm{S}$ when cyclin D1 is proteolytically degraded or B-Myb is activated by cyclin A/cdk2. In support of this hypothesis, B-Myb transcriptional activity has recently been reported to be enhanced during the early stages of neural differentiation, and this coincided with reduced association with cyclin D1 [95]. In contrast to cyclin D1, cdk9 levels are not cell cycle regulated and the physiological relevance of the interaction with B-Myb is not yet obvious.

The expression of the cyclin $A 1$ gene is restricted to a very few tissues; namely, testis, haematopoietic precursors and several myeloid leukaemic cell lines [96, 97]. Cyclin A1 interacts with the B-Myb C terminus in vitro and these proteins appear to be associated in vivo in leukaemic cells. In contrast to cyclin D1 and cdk9, cyclin A1/cdk2 induces B-Myb activity by phosphorylating key threonine and serine residues [49]. Notably, despite the great similarity between cyclin A1 and cyclin A2, no associa- 
tion between B-Myb and cyclin A2 has been detected in leukaemic cells [49], mouse embryonic stem cells or in transfection experiments [unpublished results] suggesting that the B-Myb-cyclin A1 association is highly specific. Since B-Myb is co-expressed in both male germ cells [98] and haematopoietic cells [16], it would be interesting to know its relationship with cyclin A1 in these cells.

\section{Perspectives}

The $B$-myb gene is subject to two levels of control during the cell cycle: at the transcriptional level through the action of the E2F and $\mathrm{Rb}$ family of proteins and at the posttranslational level through the action of late G1/S phasespecific kinases, in particular cyclin $\mathrm{A} / \mathrm{cdk} 2$. The first mechanism ensures that $B-m y b$ is transcribed only in proliferating cells, and directs maximal synthesis of B-Myb protein to late G1/S in cycling cells. The second mechanism ensures that the transcriptional activity of B-Myb in cycling cells, where B-Myb protein is present throughout the cell cycle (albeit at fluctuating levels), is enhanced specifically in late G1/S. The existence of these coupled regulatory modes points to the inescapable conclusion that B-Myb plays a significant role in the cell cycle during late G1/S. At present, however, we are only scratching the surface in our understanding of the precise nature of this role.

Experimental evidence points to a two-fold role for BMyb in the cell cycle: (i) by acting as a transcription factor to regulate expression of genes required for cell cycling and (ii) by making direct interactions with cell cycle regulators such as p107 and p57 Kip2. Significantly, the related Drosophila Myb protein has been shown to function both in transcriptional regulation and more directly as part of a DNA replication complex, and these studies in the fly may help us understand what B-Myb does in the mammalian cell cycle. Notable in this respect is that Drosophila Myb mutants display defects in progression through both $\mathrm{S}$ and $\mathrm{M}$ phases of the cell cycle and accumulate chromosomal abnormalities [99-101]. Conversely, over-expressing Drosophila Myb induces cell cycle progression through $\mathrm{S}$ and $\mathrm{M}$ phases and suppresses endoreduplication [102]. Although the precise effects seen in these experiments depended on the cell type analysed, the fly protein is clearly intimately involved in the cell cycle. Effects on G2/M progression have been ascribed to the involvement of Drosophila Myb in transcription of the cyclin B gene [103], while effects on G1/S progression may depend upon the induction of other Myb targets or may result from its direct role in DNA replication [88, 101].

In common with the Drosophila homologue, over-expression of $B-m y b$ has been shown to promote progression of certain cells into $S$ phase [11, 104], in particular when it is co-expressed with cyclin A. Unclear at present is whether this results from the induction of target gene transcription, direct effects upon cell cycle regulators or indeed their combination. Our experiments in Saos-2 cells indicate that the ability to interact with p107 is required for this activity, as transcriptionally hyperactive BMyb mutants which had lost the p107-binding function were unable to co-operate with cyclin A to promote $\mathrm{S}$ phase [unpublished results]. Overall, our experiments indicate that one of the major B-Myb functions contributing to $\mathrm{G} 1 / \mathrm{S}$ progression is maintenance of sufficient levels of cyclin E/cdk2 and possibly cyclin A/cdk2 activity [91]. Notably, both these kinases play vital roles in progression into and progress through $\mathrm{S}$ phase.

Gene knock-out studies have shown decisively that BMyb plays a critical role in early embryogenesis [24]. The embryonal defect is so early, however, that sufficient quantities of cells cannot be obtained from the mutant embryos to allow biochemical analyses of the defect. Conditional gene knock-outs based on the Cre/loxP system are under development, and there is now the potential to ablate $B-m y b$ expression in cell cultures using RNA interference. These developing technologies should enable rapid progress in understanding the role of B-Myb in the cell cycle.

Acknowledgements. We are grateful to the members of the laboratory for their valuable suggestions during the preparation of this manuscript. Some of the work from our laboratory reported in this review was supported by Cancer Research UK [CRC] (project grant C1317/A2275).

1 Graf T. (1992) Myb: a transcriptional activator linking proliferation and differentiation in hematopoietic cells. Curr. Opin. Genet. Dev. 2: 249-255

2 Nomura N., Takahashi M., Matsui M., Ishii S., Date T., Sasamoto S. et al. (1988) Isolation of human cDNA clones of myb-related genes, A-myb and B-myb. Nucleic Acids Res. 16: 11075-11089

3 Biedenkapp H., Borgmeyer U., Sippel A. E. and Klempnauer K. H. (1988) Viral myb oncogene encodes a sequence-specific DNA-binding. Nature 335: 835-837

4 Howe K. M. and Watson R. J. (1991) Nucleotide preferences in sequence-specific recognition of DNA by c-myb protein. Nucleic Acids Res. 19: 3913-3119

5 Weston K. and Bishop J. M. (1989) Trancriptional activation by the $\mathrm{v}$-myb oncogene and its cellular progenitor, c-myb. Cell 58: $85-93$

6 Sakura H., Kanei-Ishii C., Nagase T., Nakagoshi H., Gonda T. J. and Ishii S. (1989) Delineation of three functional domains of the transcriptional activator encoded by the c-myb protooncogene. Proc. Natl. Acad Sci. USA 86: 5758-5762

7 Nakagoshi T., Takemoto Y. and Ishii S. (1993) Functional domains of the human B-myb gene product. J. Biol. Chem. 268: 14161-14167

8 Ansieau S., Kowenz-Leutz E., Dechend R. and Leutz A. (1997) B-Myb, a repressed trans-activating protein. J. Mol. Med. 75: 815-819

9 Golay J., Loffarelli L., Luppi M., Castellano M. and Introna M. (1994) The human A-myb protein is a strong activator of transcription. Oncogene 9: 2469-2479 
10 Dubendorff J. W., Whittaker L. J., Eltman J. T. and Lipsick J. S. (1992) Carboxy-terminal elements of c-Myb negatively regulate transcriptional activation in cis and in trans. Genes Dev. 6: $2524-2535$

11 Lane S., Farlie P. and Watson R. (1997) B-Myb function can be markedly enhanced by cyclin A-dependent kinase and protein truncation. Oncogene 14: 2445-2453

12 Ziebold U., Bartsch O., Marais R., Ferrari S. and Klempnauer K.-H. (1997) Phosphorylation and activation of B-Myb by cyclin A-Cdk2. Curr. Biol. 7: 253-260

13 Facchinetti V., Loffarelli L., Schreek S., Oelgeschlager M., Luscher B., Introna M. et al. (1997) Regulatory domains of the $\mathrm{A}-\mathrm{Myb}$ transcription factor and its interaction with the CBP/p300 adaptor molecules. Biochem. J. 324: 729-736.

14 Takahashi T., Nakagoshi H., Sarai A., Nomura N., Yamamoto T. and Ishii S. (1995) Human A-myb gene encodes a transcriptional activator containing the negative regulatory domains. FEBS Lett. 358: 89-96.

15 Westin E. H., Gallo R. C., Arya S. K., Souza L. M., Baluda M., Aaronson S. A. et al. (1982) Differential expression of the amv gene in human hematopoietic cells. Proc. Natl. Acad. Sci. USA 79: $2194-2198$

16 Golay J., Capucci A., Arsura M., Castellano M., Rizzo V. and Introna M. (1991) Expression of c-Myb and B-Myb, but not A-Myb, correlates with proliferation in human hematopoietic cells. Blood 77: 149-158

17 Mucenski M. L., McLain K., Kier A. B., Swerdlow S. H., Schreiner C. M., Miller T. A. et al. (1991) A functional c-myb gene is required for normal murine fetal hepatic hematopoiesis. Cell 65: 677-689

18 Trauth K., Mutschler B., Jenkins N., Gilbert D., Copeland N. and Klempnauer K.-H. (1994) Mouse A-Myb encodes a transactivator and is expressed in mitotically active cells of the developing central nervous system, adult testis and B-lymphocytes. EMBO J. 13: 5994-6005

19 Toscani A., Mettus R., Coupland R., Simpkins H., Litvin J., Orth J. et al. (1997) Arrest of spermatogenesis and defective breast development in mice lacking A-Myb. Nature 386: $713-717$

20 Reiss K., Travali S., Calabretta B. and Baserga R. (1991) Growth regulated expression of B-Myb in fibroblasts and hematopoietic cells. J. Cell. Sci. 148: 338-343

21 Lam E. W.-F., Robinson C. and Watson R. J. (1992) Characterization and cell-cycle regulated expression of mouse BMyb. Oncogene 7: 1885-1890

22 Kamano H., Burk B., Noben-Trauth K. and Klempnauer K.H. (1995) Differential splicing of the mouse B-myb gene. Oncogene 11: 2719-2725

23 Sitzmann J., Noben-Trauth K., Kamano H. and Klempnauer K.-H. (1996) Expression of B-Myb during mouse embryogenesis. Oncogene 12: 1889-1894

24 Tanaka Y., Patestos N. P., Maekawa T. and Ishii S. (1999) Bmyb is required for inner cell mass formation at an early stage of development. J. Biol. Chem. 274: 28067-28070

25 Arsura M., Introna M., Passerini F., Montovani A. and Golay J. (1992) B-Myb antisense oligonucleotides inhibit proliferation of human hematopoietic cell lines. Blood 79: 2708-2716

26 Sala A. and Calabretta B. (1992) Regulation of BALB/c3T3 fibroblast proliferation by B-Myb is accompanied by selective activation of $c d c 2$ and cyclin D1 expression. Proc. Natl. Acad. Sci. USA 89: 10415-10419

27 Lin D., Fiscella M., O'Connor P. M., Joany J., Chen M., Luo L. L. et al. (1994) Constitutive expression of B-myb can bypass p53-induced Waf1/Cip1-mediated $\mathrm{G}_{1}$ arrest. Proc. Natl. Acad. Sci. USA 91: 10079-10083

28 Raschellá G., Negroni A., Sala A., Pucci S., Romeo A. and Calabretta B. (1995) Requirement of B-Myb function for survival and differentiative potential of human neuroblastoma cells. J. Biol. Chem. 270: $8540-8545$
29 Bies J., Hoffman B., Amanullah A., Giese T. and Wolff L. (1996) B-Myb prevents growth arrest associated with terminal differentiation of monocytic cells. Oncogene 12: 355-363

30 Lam E. W.-F., Bennet J. D. and Watson R. J. (1995) Cell-cyle regulation of human B-myb transcription. Gene 160: 277-281

31 Lam E. W.-F. and Watson R. J. (1993) An E2F-binding site mediates cell-cycle repression of B-Myb mouse transcription. EMBO J. 12: 2705-2713

32 Lam E. W.-F., Morris J. D. H., Davies R., Crook T., Watson R. J. and Vousden K. H. (1994) HPV16 E7 oncoprotein deregulates B-myb expression: correlation with targeting of p107/E2F complexes. EMBO J. 13: 871-878

33 Bennett J. D., Farlie P. and Watson R. J. (1996) E2F binding is required but not sufficient for repression of B-Myb transcription in quiescent fibroblasts. Oncogene 13: 1073-1082

34 Hurford R. K., Cobrinik D., Lee M.-H. and Dyson N. (1997) $\mathrm{pRb}$ and $\mathrm{p} 107 / \mathrm{p} 130$ are required for the regulated expression of different sets of E2F responsive genes. Genes Dev. 11: $1447-1463$

35 Catchpole S., Tavner F., Le Cam L., Sardet C. and Watson R. (2002) A B-myb promoter corepressor site facilitates in vivo occupation of adjacent E2F site by p107/E2F and p130/E2F complexes. J. Biol. Chem 277: 39015-39024

36 Zwicker J., Liu N., Engeland K., Lucibello F. C. and Müller R. (1996) Cell cycle regulation of E2F site occupation in vivo. Science 271: $1595-1597$

37 Wells J., Boyd K. E., Fry C. J., Bartley S. M. and Farnham P. J. (2000) Target gene specifity of E2F and pocket protein family members in living cells. Mol. Cell. Biol. 20: 5797-5807

38 Takahashi Y., Rayman J. B. and Dynlacht D. (2000) Analysis of promoter binding by the E2F and $\mathrm{pRB}$ families in vivo: distinct E2F proteins mediate activation and repression. Genes Dev. 14: $804-816$

39 Humbert P. O., Verona R., Trimarchi J. M., Rogers C., Dandapani S. and Lees J. A. (2000) E2F3 is critical for normal cellular proliferation. Genes Dev. 14: 690-703

40 Rayman J. B., Takahashi Y., Indjeian V. B., Dannenberg J.-H., Catchpole S., Watson R. J. et al. (2002) E2F mediates cell cycle-dependent transcriptional repression in vivo by recruitment of an HDAC $1 / \mathrm{mSin} 3 \mathrm{~B}$ corepressor complex. Genes Dev. 16: $933-947$

41 Zhang H. S., Postigo A. A. and Dean D. C. (2000) Active transcriptional arrest by the Rb-E2F complex mediates G1 arrest triggered by $\mathrm{p} 16^{\mathrm{INK} 4 \mathrm{a}}, \mathrm{TGF} \beta$ and contact inhibition. Cell 97: $53-61$

42 Satterwhite D. J., Aakre A. E. and Moses H. L. (1994) Inhibition of cell growth by TGF beta 1 is associated with inhibition of B-myb and cyclin A in both BALB/MK and MvLu cells. Cell Growth Differ. 5: 789-799

43 Chen C.-R., Kang Y., Siegel P. M. and Massagué J. (2002) E2F4/5 and p107 as Smad cofactors linking the TGF $\beta$ receptor to c-myc repression. Cell 110: 19-32

44 Robinson C., Light Y., Groves R., Mann D., Marais R. and Watson R. (1996) Cell-cycle regulation of B-Myb protein expression: specific phosphorylation during the $\mathrm{S}$ phase of the cell cycle. Oncogene 12: 1855-1864

45 Hall M. and Peters G. (1996) Genetic alterations of cyclins, cyclin-dependent kinases, and Cdk inhibitors in human cancer. Adv. Cancer Res. 68: 67-108

46 Saville M. K. and Watson R. J. (1998) The cell-cycle regulated transcription factor B-Myb is phosphorylated by cyclin $\mathrm{A} / \mathrm{cdk} 2$ at sites that enhance its transcriptional activity. Oncogene 17: 1679-1689

47 Sala A., Kundu M., Casella I., Engelhard A., Calabretta B., Grasso L. et al. (1997) Activation of human B-Myb by cyclins. Proc. Natl. Acad. Sci. USA 94: 532-536

48 Bartsch O., Hortsmann S., Toprak K., Klempnauer K.-H. and Ferrari S. (1999) Identification of cyclin A/cdk2 phosphorylation sites in B-Myb. Eur. J. Biochem. 260: 384-391 
49 Müller-Tidow C., Wang W., Idos G. E., Diederichs S., Yang R., Readhead C. et al. (2001) Cyclin A1 directly interacts with BMyb and cyclin A1/cdk2 phosphorylates B-Myb at functionally important serine and threonine residues: tissue-specific regulation of B-Myb function. Blood 97: 2091-2097

50 Johnson R. K., Schweppe R. E., Septer J. and Lewis R. J. (1999) Phosphorylation of B-Myb regulates its transcriptional potential and DNA binding. J. Biol. Chem. 274: 36741-36749

51 Johnson L. R., Johnson T. K., Desler M., Luster T. A., Nowling T., Lewis R. E. et al. (2002) Effects of B-MYB on gene transcription. J. Biol. Chem. 277: 4088-4097

52 Bessa M., Saville M. K. and Watson R. J. (2001) Inhibition of cyclin $\mathrm{A} / \mathrm{Cdk} 2$ phosphorylation impairs B-Myb transactivation function without affecting interactions with DNA or the CBP coactivator. Oncogene 20: 3376-3386

53 Li X. and McDonnell D. P. (2002) The transcription factor BMyb is maintained in an inhibited state in target cells through its interaction with the nuclear corepressors N-CoR and SMRT. Mol. Cell. Biol. 22: 3663-3673

54 Chan H. M. and La Thangue N. B. (2001) p300/CBP proteins: HATs for transcriptional bridges and scaffolds. J. Cell Sci. 114: $2363-2373$

55 Sano Y. and Ishii S. (2001) Increased affinity of c-Myb for CREB-binding protein (CBP) after CBP-induced acetylation. J. Biol. Chem. 276: 3674-3682

56 Tomita A., Towatari M., Tsuzuki S., Hayakawa F., Kosugi H., Tamai K. et al. (2000) c-Myb acetylation at the carboxy-terminal conserved domain by transcriptional co-activator p300. Oncogene 19: 444-451

57 Cervellera M. N. and Sala A. (2000) Poly(ADP-ribose) polymerase is a B-MYB coactivator. J. Biol. Chem. 275: $10692-10696$

58 Santilli G., Cervellera M. N., Johnson T. K., Lewis R. E., Iacobelli S. and Sala A. (2001) PARP co-activates B-MYB through enhanced phosphorylation at cyclin/cdk2 sites. Oncogene 20: $8167-8174$

59 Masselink H., Vastenhouw N. and Bernards R. (2001) B-myb rescues ras-induced premature senescence, which requires its transactivation domain. Cancer Lett. 171: 87-101

60 Jepsen K. and Rosenfeld M. G. (2002) Biological roles and mechanistic actions of co-repressor complexes. J. Cell Sci. 115: $689-698$

61 Hateboer H., Gennissen Y. F., Ramos R. M., Kerkhoven V., Sonntag-Buck H. G., Stunnenberg R. et al. (1995) BS69, a novel adenovirus E1A-associated protein that inhibits E1A transactivation. EMBO J. 14: 3159-3169

62 Elledge S. J. and Harper J. W. (1998) The role of protein stability in the cell cycle and cancer. Biochim. Biophys. Acta 1377: M61-M70

63 Desterro J. M. P., Rodriguez M. S. and Hay R. T. (2000) Regulation of transcription factors by protein degradation. Cell. Mol. Life Sci. 57: 1207-1219

64 Charrase S., Carena I., Brondani V., Klempnauer K.-H. and Ferrari S. (2000) Degradation of B-Myb by ubiquitin-mediated proteolysis: involvement of the Cdc34-SCF ${ }^{455 k p 2}$ pathway. Oncogene 19: 2986-2995

65 Iwai N., Kitajima K., Sakai K., Kimura T. and Nakano T. (2001) Alteration of cell adhesion and cell properties of ES cells by an inducible dominant interfering Myb mutant. Oncogene 20: $1425-1434$

66 Bergholtz S., Andersen T. O., Anderson K. B., Borrebæk J., Lüscher B. and Gabrielsen O. S. (2001) The highly conserved DNA binding domains of A-, B- and c-Myb with respect to DNA binding, phosphorylation and redox properties. Nucleic Acids Res. 29: $3546-3556$

67 Milarski K. L. and Morimoto R. I. (1986) Expression of human HSP70 during the synthetic phase of the cell cycle. Proc. Natl. Acad. Sci. USA 83: 9517-9521
68 Foos G., Natour S. and Klempnauer K.-H. (1993) TATA-box dependent trans-activation of the human HSP70 promoter by MYB proteins. Oncogene 8: 1775-1782

69 Watson R. J., Robinson C. and Lam E. W.-F. (1993) Transcription regulation by murine $\mathrm{B}-m y b$ is distinct from that by c-myb. Nucleic Acids Res. 21: 267-272

70 Sala A., Saitta B., De Luca P., Cervellera M. N., Casella I., Lewis R. E. et al. (1999) B-Myb transactivates its own promoter through SP1-binding sites. Oncogene 18: 1333-1339

71 Nakagoshi H., Kanei-Ishii C., Sawazaki T., Mizuguchi G. and Ishii S. (1992) Transcriptional activation of the c-myc gene by the c-myb and B- $m y b$ gene products. Oncogene 7: 1233-1240

72 Brandt T. L., Fraser D. J., Leal S., Halandras P. M., Kroll A. R. and Kroll D. J. (1997) c-Myb trans-activates the human DNA topoisomerase II $\alpha$ gene promoter. J. Biol. Chem. 272: $6278-6284$

73 Müller C., Yang R., Idos G., Tidow N., Diederichs S., Koch O. M. et al. (1999) c-myb transactivates the human cyclin A1 promoter and induces cyclin A1 gene expression. Blood 94: $4255-4262$

74 Tanno B., Negroni A., Vitali R., Pirozzoli M. C., Cesi V., Mancini C. et al. (2002) Expression of insulin-like growth factor-binding protein 5 in neuroblastoma cells is regulated at the transcriptional level by c-Myb and B-Myb via direct and indirect mechanisms. J. Biol. Chem. 277: 23172-23180

75 Cervellera M., Raschella G., Santilli G., Tanno B., Ventura A., Mancini C. et al. (2000) Direct transactivation of the antiapoptotic gene apolipoprotein J (clusterin) by B-Myb. J. Biol. Chem. 275: 21055-21060

76 Trougakos I. P. and Gonos E. S. (2002) Clusterin/apolipo-protein $\mathrm{J}$ in human aging and cancer. Int. J. Biochem. Cell Biol. 34: $1430-1448$

77 Raschellá G., Cesi V., Amendola R., Negroni A., Tanno B., A1tavista P. et al. (1999) Expression of B-myb in neuroblastoma tumors is a poor prognostic factor independent from MYCN amplification. Cancer Res. 59: 3365-3368

78 Grassilli E., Salomoni P., Perrotti D., Franseschi C. and Calabretta B. (1999) Resistance to apoptosis in CTLL2 cells overexpressing B-Myb is associated with B-Myb-dependent bcl-2 induction. Cancer Res. 59: 2451-2456

79 Bruno M. D., Whitsett J. A., Ross G. F. and Korfhagen T. R. (1999) Transcriptional regulation of the murine surfactant protein-A gene by B-Myb. J. Biol. Chem, 275: $27523-$ 27528

80 Mizuguchi G., Kanei-Ishii C., Takahashi T., Yasukawa T., Nagase T., Horikoshi M. et al. (1995) c-Myb repression of cerbB-2 transcription factor by direct binding to the c-erbB2 promoter. J. Biol. Chem. 270: 9384-9389

81 Slamon D. J., Clark G. M., Wong S. G., Levin W. J., Ullrich A. and McGuire W. L. (1987) Human breast cancer: correlation of relapse and survival with amplification of the HER2/neu oncogene. Science 235: 177-182

82 Marhamati D. J. and Sonenshein G. E. (1996) B-Myb expression in vascular smooth muscle cells occurs in a cell cycle-dependent fashion and down-regulates promoter activity of type I collagen genes. J. Biol. Chem. 271: 3359-3365

83 Kypreos K. E., Nugent M. A. and Sonenshein G. E. (1998) Basic fibroblast growth factor-induced decrease in type I collagen gene transcription is mediated by B-Myb. Cell Growth Differ. 9: 723-730

84 Luchetti M. M., Paroncini P., Majlingova P., Frampton J., Mucenski M., Svegliati Baroni S. et al. (2002) Characterization of the c-Myb-responsive region of the human type I collagen $\alpha 2$ chain gene. J. Biol. Chem. 278: 1533-1541

85 Kypreos K. E., Marhamati D. J. and Sonhenshein G. E. (1999) $\mathrm{B}-\mathrm{Myb}$ represses trans-activation of the Col5A2 collagen promoter indirectly via inhibition of binding of factors interacting with positive elements within the first exon. Matrix Biol. 18: $275-285$ 
86 Horstmann S., Ferrari S. and Klempnauer K.-H. (2000) Regulation of B-Myb activity by cyclin D1. Oncogene 19: 298-306

87 Sala A., De Luca A., Giordano A. and Peschle C. (1996) The retinoblastoma family member 107 binds to B-Myb and supresses its autoregulatory activity. J. Biol. Chem. 271: 28738-28740

88 Beall E. L., Manak J. R., Zhou S., Bell M., Lipsick J. S. and Botchan M. R. (2002) Role for a Drosophila Myb-containing protein complex in site-specific DNA replication. Nature 420: $833-837$

89 Simon A. L., Stone E. A. and Sidow A. (2002) Inference of functional regions in proteins by quantification of evolutionary constraints. Proc. Natl. Acad. Sci. USA 99: 2912-2917

90 Classon M. and Dyson N. (2001) p107 and p130: versatile proteins with interesting pockets. Exp. Cell Res. 264: $135-147$

91 Joaquin M., Bessa M., Saville M. K. and Watson R. J. (2002) B-Myb overcomes a p107-mediated cell proliferation block by interacting with an $\mathrm{N}$-terminal domain of $\mathrm{p} 107$. Oncogene 21: 7923-7932

92 Zhu L., Enders G., Lees J. A., Beijersbergen R. L., Bernards R. and Harlow E. (1995) The pRb-related protein p107 contains two growth suppression domains: independent interactions with E2F and cyclin/cdk complexes. EMBO J. 14: 1904-1913

93 Zhu L., Harlow E. and Dynlacht D. (1995) p107 uses a $\mathrm{p} 21^{\mathrm{CIP1}}$-related domain to bind cyclin/cdk2 and regulate interactions with E2F. Genes Dev. 9: 1740-1752

94 De Falco G., Bagella L., Claudio P. P., Luca A. de, Fu Y., Calabretta B. et al. (2000) Physical interaction between CDK9 and B-Myb results in supression of B-Myb gene autoregulation. Oncogene 19: 373-379

95 Cesi V., Tanno B., Vitali R., Mancini C., Giuffrida M. L., Calabretta B. et al. (2002) Cyclin D1-dependent regulation of B-Myb activity in early stages of neuroblasotoma differentiation. Cell Death Differ. 9: 1232-1239
96 Yang R., Morosetti R. and Koeffler H. P. (1997) Characterization of a second human cyclin A that is highly expressed in testis and in several leukemia cell lines. Cancer Res. 57: 913-920

97 Yang R., Nakamaki T., Lubbert M., Said J., Sakashita A., Freyaldenhoven B. S. et al. (1999) Cyclin A1 is expressed in blasts of leukemic patients and during hematopoiesis. Blood 93: $2067-2074$

98 Latham K. E., Litvin J., Orth J. M., Patel B., Mettus R. and Reddy E. P. (1996) Temporal patterns of A-Myb and B-Myb gene expression during testis development. Oncogene 13: $1161-1168$

99 Katzen A. L., Jackson J., Harmon B. P., Fung S. M., Ramsay G. and Bishop J. M. (1998) Drosophila myb is required for the G2/M transition and maintenance of diploidy. Genes Dev. 12: 831-843.

100 Fung S. M., Ramsay G. and Katzen A. L. (2002) Mutations in Drosophila myb lead to centrosome amplification and genomic instability. Development 129: 347-359.

101 Manak J. R., Mitiku N. and Lipsick J. S. (2002) Mutation of the Drosophila homologue of the Myb protooncogene causes genomic instability. Proc. Natl. Acad. Sci. USA 99: $7438-7443$.

102 Fitzpatrick C. A., Sharkov N. V., Ramsay G. and Katzen A. L. (2002) Drosophila myb exerts opposing effects on S phase, promoting proliferation and suppressing endoreduplication. Development 129: 4497-507.

103 Okada M., Akimaru H., Hou D. X., Takahashi T. and Ishii S (2002) Myb controls G(2)/M progression by inducing cyclin $\mathrm{B}$ expression in the Drosophila eye imaginal disc. EMBO J. 21: $675-684$

104 Sala A., Casella I., Bellon T., Calabretta B., Watson R. J. and Peschle C. (1996) B-myb promotes S phase and is a downstrean target of the negative regulator p107 in human cells. J. Biol. Chem. 271: 9363-9367 